Revta bras. Zool.,

\title{
MUSEU NACIONAL DE HISTÓRIA NATURAL
}

\author{
José Cândido de Melo Carvalho, Ph.D. ${ }^{1}$
}

Um Museu Nacional de História Natural geralmente está situado na Capital do país. Entre seus objetivos básicos mencionarei:

Coligir, classificar e conservar acervo relativo as ciências naturais da nação e de outros países. Geralmente esse tipo de museu é ligado ao Ministério da Educação ou Fundações. Ele costuma ser tanto mais rico e variado (representativo), quanto maior for o número de especialistas em Historia Natural que possuir e quanto maior forem seus recursos para pesquisa interna e externa, inclusive ex. pedições no território nacional e no exterior.

Ocasionalmente engaja os serviços científicos de especialistas do exterior, a fim de melhor estudar seu acervo. Costuma ser representativo do país de origem, podendo no entanto estender suas atividades a outras regiões ou mesmo ser cosmopolita. Embora muitos deles terem surgidos no século passado, costumam ter elementos representativos da geologia, botânica, zoologia e antropologia, atuais e anteriores.

O acervo de um Museu Nacional de História Natural tem duas finalidades precípuas:

a) permitir o estudo e pesquisas em assuntos relacionados com as ciências naturais. Eles podem relacionar-se à aspectos morfológicos, anatômicos, histológicos, reprodutivos, embriológicos, genéticos, evolutivos, etológi$\cos$, distribuição geográfica e ecológica, paleontológicos, tax onômicos ou sistemáticos. Permitem associar a observação à experimentação, discernir fatos de crenças (mitos), obter dados qualitativos e quantitativos, seres endêmicos ou exóticos, etc.

Um exemplo típico de um Museu Nacional de Historia Natural: em 1951, tive oportunidade de estudar os Insetos hemípteros da família dos mirídeos da Coleção P.W. Lund, depositados no Museu de Copenhague. Entre eles, além de ter descrito um gênero (Lundiella) em homenagem ao ilustre sábio, encontrei um pequeno exemplar colecionado em Lagoa Santa (1847) por Reinhardt, quando ali estivera em visita a Lund, por ocasião da primeira viagem de circunavegação conhecida como Galathéa (1845 - 1847). Após peregrinar com o bichinho pelos museus europeus e americanos, só recentemente, 120 anos depois, pude batizálos com Eurotas reinhardti n.sp. Esse fato permitiu conhecer antecedentes históricos, flora da região, associação geográfica com outras de Mato Grosso e Panamá, entre outras cousas.

b) educação de massa (povão) da população do país e do exterior, através de exposições públicas, abrangendo todas as faixas etárias. Nelas geral-

1 Museu Nacional, Rio de Janeiro, RJ. 
Revta bras. Zool.

mente mostra-se aquilo que é mais representativo de uma região entre animais, vegetais, rochas, minerais e o próprio homem (atual e passado). Como exemplos de museus desse tipo citarei: Museu Britânico (com seus vários setores), a Instituição Smithsoniana, Museu de Paris, Museu de História Natural ou Museu de Antropologia do México, Museu Nacional do Peru, Museu de História Natural de Estocolmo, etc., onde se pode ver desde os grandes fósseis coligidos por Darwin na Patagonia, latiméria, dodo e outras raridades, algumas das quais já extintas.

As exposições públicas disseminam cultura e educação. Segundo Roquette Pinto: "um museu, em país de formação étnica não definida, onde as massas populares têm admiráveis faculdades nativas em grande parte anuladas pela bruta ignorância em que se debatem, deve ser, antes de tudo, casa de ensino, casa de educação". . . "escola que ensina a todos . . . escola que ensina tudo"! Ainda desse mestre a observação: "Cumpre-me deixar bem claro, por via das dúvidas, que os institutos essencialmente consagrados à pesquisa científica superior. . . não deverão, em hipótese alguma, prejudicar a sua elevada finalidade, transformandose em simples escolas das chamadas superiores do tipo corrente".

Um Museu Nacional de História Natural é uma instituição para o povo, para a educação e para a ciência.

Cabe ainda a um Museu Nacional divulgar conhecimentos de ciências naturais e resultados de estudos que tiver realizado por meio de publicações, palestras, conferências, cursos, assistência aos interessados, TV, rádio, imprensa, etc.

Para alcançar esses objetivos um Museu Nacional de História Natural deverá ter, pelo menos, a seguinte organização: administração central (Diretoria e subseqüentes, com seus anexos): Portaria, Secretaria, Contabilidade, Serviço de Pessoal, Almoxarifados, Oficinas e outros serviços necessários a uma boa administração.

Fundamental para um bom desempenho são as Divisões Técnico-Científicas: Antropologia, Geologia e Mineralogia, Botânica, Zoologia e Extensão Cultural ou Educação, com seus respectivos anexos: Biblioteca, Taxidermia, Desenho, Fotografia, Horto botânico isolado ou associado com animais vivos, áreas de campo para pesquisa e experimentação. A Divisão de Exposições Públicas é também fundamental. Existem setores básicos: Edifício para material em meio líquido (álcool, etc), depósito de tipos, coleções científicas e pessoal habilitado para ampliá-las e mantê-las, en tre outros.

O chamado Museu Nacional (de História Natural) do Rio de Janeiro, possui atualmente posição "sui-generis". Dedicado ao estudo das ciências naturais, nasceu em 1779 com a Casa dos Pássaros, sendo posteriormente seu acervo e pessoal incorporado ao Museu Real (1818), criado por D. João VI. Ao ser proclamada a República passou a Museu Nacional (1889). Já esteve em 7 Ministérios, sendo integrado como Instituição Nacional a Universidade do Brasil (1941) e incorporado à Universidade Federal do Rio de Janeiro. Até o presente teve 20 Diretores.

Instalado no Palácio de São Cristóvão (1892), Quinta da Boa Vista, em prédio antigo, no qual viveu a família Imperial cerca de 80 anos, possui pouca segurança contra incêndio, é muito vulnerável a pragas (cupins), deixando muito a desejar como sede de um Museu Nacional de História Natural. 
Vol. 5(4), 1988

Nos seus 208 anos de existência (com altos e baixos), conseguiu reunir o seguinte acervo: Geologia 23.119 peças; Botânica 509.730; Zoologia 312.756; Antropologia 100.000. A Biblioteca possui acima de 370.000 unidades.

Possui como publicações: Arquivos do Museu Nacional (1876 -); Boletim do Museu Nacional (1923 - 1942); Boletim do Museu Nacional, Nova Série: Antropologia, Geologia, Botânica, Zoologia (1942 -); Publicações Avulsas $(1945$-) e outras, inclusive relatórios e livros. A Revista do Museu Nacional (1944 - 1945) teve vida efêmera.

Atualmente ministra cursos em Ciências Sociais (Mestrado e Doutorado); Botânica (Mestrado); Zoologia (Mestrado).

$\mathrm{O}$ orçamento recebido para custeio em 1986 foi de $\mathrm{Cz} \$ 500.000,00$ (quinhentos mil cruzados). O Governo Federal paga ao pessoal do Quadro da Universidade do Rio de Janeiro, lotado no Museu Nacional, a quantia de Cz\$ $6.658 .951,00$.

A meu ver, deveria fazer parte de uma Fundação D. João VI, juntamente com o Jardim Botânico e o Observatório Nacional. Necessita urgentemente de um novo edifício para as Divisões Técnico-Científicas, a fim de retomar seu desenvolvimento e ter maior segurança de seu acervo. A presente situação é exdrúxula: Museu Nacional, na Universidade Federal do Rio de Janeiro.

\section{BIBLIOGRAFIA}

Carvalho, J.C.M. 1977. Museu Nacional, Boletim Conselho Federal Cultura, 28 (julho/agosto/setembro), 68 páginas. 